\title{
Temperament and reproductive biology: emotional reactivity and reproduction in sheep
}

\author{
Dominique Blache ${ }^{1}$, Samantha L. Bickell ${ }^{1}$ \\ 1 School of Animal Biology M085, Faculty of Natural \& Agricultural Sciences, The University of Western Australia, 35 Stirling Highway, Crawley, \\ WA 6009, Australia. Tel: +61 86488 3587; Fax: +61 864881040
}

ABSTRACT - Reproductive capacity is controlled by a large number of factors such as season, social interactions and metabolic status. However, the influence of emotional reactivity on reproductive success has not been intensively investigated in farm animals. In this review, we define emotion reactivity and the expression of its inter individual variability named temperament. We briefly describe our protocol to measure temperament in sheep and discuss the heritability of temperament traits. Using the results obtained from our flock of sheep selected for calm or nervous temperament, we illustrate how this selection affects the reproductive biology from changing the inexperienced ewe's response to the male effect to improving lamb survival and ovulation rate. We conclude that the mechanisms by which selection for temperament affects the different steps of the reproductive cycle are not yet understood but nevertheless this type of selection could have a great impact on reproduction efficiency of sheep and other domestic ruminants.

Key Words: male effect, ovulation, sheep, survival, temperament

\section{Biologia temperamental e reprodutiva: reatividade emocional e reprodução em ovinos}

\begin{abstract}
RESUMO - A capacidade reprodutiva é controlada por fatores como estação do ano, interações sociais e estado metabólico. Entretanto, a influência da reatividade emocional no sucesso reprodutivo ainda não foi intensivamente investigada nos rebanhos. Nesta revisão, definimos reatividade emocional e a sua expressão da variabilidade individual denominada temperamento. Descrevemos de forma reduzida um protocolo para mensurar o temperamento em ovinos e discutir a herdabilidade das características do temperamento. Utilizando resultados obtidos de nossos rebanhos de ovinos selecionados para temperamento calmo ou nervoso, apresentamos como esta seleção afeta a biologia reprodutiva pela mudança na resposta da ovelha para o efeito do macho para melhorar a sobrevivência do cordeiro e a taxa de ovulação. Nós concluímos que os mecanismos pelos quais a seleção para temperamento afeta os diferentes passos do ciclo reprodutivo ainda não são bem compreendidos. No entanto, este tipo de seleção poderia ter grande impacto na eficiência reprodutiva de ovinos e outros ruminantes domésticos.
\end{abstract}

Palavras-chave: efeito macho, ovinos, ovulação, sobrevivência, temperamento

\section{Introduction}

Reproductive function is controlled by a large range of external factors such as season, nutrition, social structure and stress (Blache, 2003; Rosa, 2003; Delgadillo, 2009). In a recent review, we have summarized the intricacies of these relationships using a model, based on our work on the relationship between nutrition and reproduction, and articulated around four interdependent 'dimensions': genetic, structural, communicational and temporal (Blache et al., 2006). Briefly, the genetic dimension includes species, breed and individual differences. The structural dimension includes all organs involved in the regulation of the reproductive axis. The communication dimension includes physiological systems that can either generate endocrine, neural and nutrient-based signals or sense those same signals. The temporal dimension encompasses the time dependent regulation of the reproductive axis such as changes in response to particular nutrients or responses of regulatory hormones associated with previous changes in body condition. Of the four dimensions, the genetic dimension has been the most altered thru domestication and by classical or modern genetic selection during the few centuries of animal farming. While domestication has primarily modified the capacity of animals to "adapt to man and the environment he provides" (Price, 2002), genetic selection has targeted production traits such as wool, milk or milk quality and quantity (Willis, 1991). It has been 
shown that selection for high producing animals has also led to a decrease in their reproductive capacity, as very clearly illustrated by the high producing dairy cow (Rauw et al., 1998). In this review, we argue that genetic selection for temperament traits can improve the reproductive capacity by modifying the physiology and biology of the animal. We will mainly base our arguments on data obtained in sheep and where possible other ruminants.

\section{Emotion and temperament in animal}

The existence of emotion in animals has been recognized by Darwin who suggested that animals experience both negative (fear, frustration) and positive (pleasure) emotions (Darwin, 1872). It must be noted that Darwin did not recognise that ruminants "displayed in so slight a degree their emotions or sensations" (Darwin, 1872). The existence of emotion in animals have been widely debated, however, an emotion, as defined by the appraisal theories developed in psychology, results from the sequential evaluation of the triggering situation based on elementary characteristics (suddenness, unfamiliarity and pleasantness of the situation and an individuals ability to predict and to control it). Research in sheep has shown that animals use the same elementary characteristics as humans to evaluate their environment, suggesting that ruminants have emotional experience (Boissy, 1995) as suggested by Darwin in other species (Darwin, 1872). For example, sheep exposed to an unfamiliar and unpleasant situation elicits either fear if the individual cannot control it or anger if the situation is under its control (Greiveldinger et al., 2007).

There is large variability in the emotional reactivity between animals and this variability is a phenotypic trait that has been named temperament. Temperament has been defined for humans as 'nature controlling the way he behaves, feels and thinks' (Cannon, 1927). For animals, many attempts have been made to apply similar criteria on the basis of our perceptions of their 'temperament'. Boissy (1995) concluded that emotional reactivity has a significant impact on the relationship of an animal to its environment and that non-human animals have personality, temperament or individual behaviours, amongst which fearfulness plays an important role in an individual's behavioural response to threatening situations. In addition, repeated emotions can bias cognitive functions such as judgement and decisionmaking, which explain how temperament traits can be strongly expressed. It is only very recently that the nature of emotions in animals and the way to assess their temperament have been under investigation (Boissy et al., 2007). In applied research in farm ruminants, a large number of investigations were conducted to select for temperament with the objective to either decrease handling risk in cattle or improving the survival of the newborn sheep (Forkman et al., 2007). However, the effect of temperament on the behaviour or physiology of animals can only be studied if a reliable and discriminative measure of temperament is available.

\section{How to measure temperament}

A number of methods have been designed on the basis of the above two definitions to measure either fear reaction or temperament in domesticated species such as sheep, cattle, chickens and horses (Manteca, 1993; Forkman, 2007). For cattle, such assessments have included subjective measures such as observations of crush behaviour or objective measures of escape and/or avoidance behaviours such as flight time (Voisinet et al., 1997; Fell et al., 1999). Flight-time, measured as the speed of escape from a crushing carte or a scale, assess the reaction to both isolation and human contact, has been extensively used because it is a very rapid test and it has been linked to production traits, such as meat quality (King et al., 2006). In contrast, most validated tests developed for sheep that have some degree of reliability are time consuming (from 1 to $15 \mathrm{~min}$ ) and use complex test designs (Forkman et al., 2007), and therefore are not adapted to farming system dealing with thousands of animals. A $30 \mathrm{sec}$ isolation test to measure temperament in sheep has been developed (Blache \& Ferguson, 2005) and has been used to establish the association of the temperament traits and production traits. This simple and reliable test is derived from the testing procedure that was developed for the creation of our unique flock of sheep, the "Allandale flock" in 1990.

\section{Sheep selected for temperament}

Since 1990, the "Allandale flock", a genetically selected flock of sheep, has been maintained at The University of Western Australia. This flock comprises 2 lines divergently selected for "temperament". The behaviour of the animals is measured at weaning (14-16 weeks old) during two behavioural tests; the open field test and an isolation box test (Putu, 1988; Murphy, 1999). During the open field test the sheep are conflicted between approaching a human so that they can be close to conspecifics who are located behind the human or to stay away from the human but remain isolated. The number of zones crossed during the arena test is taken as an indicator of the behavioural activity of the individual (Total Cross).

The second test, the isolation box test, involves isolating an animal in a $1.5 \mathrm{~m}^{3}$ solid plywood box for a 1 minute. An objective measure of its agitation is measured via a purpose built 'agitation meter' attached to the box which records vibrations produced by the animal's 
movement and vocalisations inside the box (BOX). The principle of the test is based on a sheep's inherent aversion of being isolated and separated from their conspecifics. Sheep are ranked within each line according to the following selection score, where $\mathrm{i}$ = individual score, $\mathrm{x}=$ flock mean, sd = standard deviation of mean (Murphy et al., 1994; Murphy, 1999):

Selection index $=100+\left[\frac{\text { BOXi }- \text { BOXx }}{\text { BOXsd }}\right]+\left[\frac{\text { TOTAL CROSSi }- \text { TOTAL CROSS } x}{\text { TOTAL CROSSsd }}\right]$

The sheep that have a low level of behavioural activity are labelled "calm” while the sheep that have a high level of behavioural activity are labelled "nervous”. Sires presenting the lowest selection score (i.e the less active in both tests) will be used to breed the calm line, conversely, the sires with the highest score will be used to breed the nervous line. Females are tested but not selected.

\section{Inheritance of temperament}

Temperament in farm animals, such as sheep, cattle and quail, has a strong genetic basis. In sheep, the temperament of young lambs born from a calm or nervous mother is not affected by the genotype of the rearing mother as demonstrated with a cross-fostering experiment (Bickell et al., 2009b). Briefly, the temperament of the cross fostered progeny was assessed at two occasions, one week after birth by measuring locomotor activity during an open-field test and at weaning (16 weeks) by measuring locomotor activity during an arena test and agitation score measured during an isolation box test. At both time points, there was a genotype effect but no maternal or fostering effect on the lamb's behaviour suggesting that temperament in Merino sheep is mainly determined by the genetic transmission of the trait rather than behaviours learned from the mother.

The heritability of different parameters used to measure the phenotypic expression of temperament/ emotion varies from low to moderate ( 0.2 to 0.4$)$ and thus genetic improvement can be achieved. Similar values of heritability of temperament traits ( 0 to 0.6 ) have been measured in cattle (Le Neindre et al., 1998; Schmutz et al., 2001; Phocas et al., 2006).

\section{Animal temperament and reproductive biology}

Some of the differences in the reproductive biology between the sheep of the two lines of the "Allandale Flock" are somewhat explicable because of the objectives of the selection, some others are not. Overall it is understandable that a reduction of fear and emotional reactivity affects reproduction because the reproductive endocrine axis can be profoundly influenced by stress, as has been clearly demonstrated for farm animals (Von Borell et al., 2007). In fact, the domestication of mammals illustrates that temperament, or emotional reactivity or tameness, affects reproductive capacity and reproductive physiology, either directly or indirectly (Price, 2002). In sheep, so far, the selection for temperament have been demonstrated to affect the behaviour of the females during the mating period and in the early stages of gestation and on the survival of newborn lambs.

\section{Mating period}

Ram behaviour of calm and nervous sires is similar between both lines. This result is not very surprising considering the intensity of the sex-drive in rams (Delgadillo et al., 2009). The introduction of a male to seasonally anoestrous ewes triggers an increase in gonadotrophin secretion in ewes that induces ovulation, a phenomenon known as the 'ram effect' (Delgadillo et al., 2009). The ram effect is a practical method for mating ewes outside the natural breeding season, and can also provide synchronised lambing. A higher proportion of nervous ewes were cycling after ram introduction than calm ewes, but only in the ewes that were sexually inexperienced (Chanvallon et al., 2010). No effect of temperament in the sexually experienced ewes suggests that the effect of temperament could be neutralized by sexual experience (Chanvallon et al., 2010). It is interesting to note that, in the nervous inexperienced ewes that responded to the introduction to the male 1) a lower proportion of nervous inexperienced ewes had delayed cycles than calm inexperienced ewes and 2) exhibited more cycles (short and normal cycles) than the calm inexperienced ewes (Chanvallon et al., 2010). The causes and mechanisms of the delayed onset and the maintenance of ovarian activity still need to be investigated. As well as influencing the response to the male effect, calm temperament also modifies the expression of reproductive behaviour in sexually inexperienced females (maiden ewes), leading to an increase in proceptivity (search for the male, Figure 1a) but not receptivity (acceptance of mating; Gelez, 2003). Overall, the selection for calm temperament could decrease the stress induced by the novelty of the contact with the male, the male being a novel experience for the maiden ewes. In fact, we have collected data showing that nervous ewes have a greater stress response than calm ewes, as measured by their agitation and plasma cortisol levels, when exposed to a novel stressor or when they anticipated a stressful event (Figure 2). These results suggest that the nervous ewes not only have a difference in stress responses but have also a different level of “anxiety”. 
a)

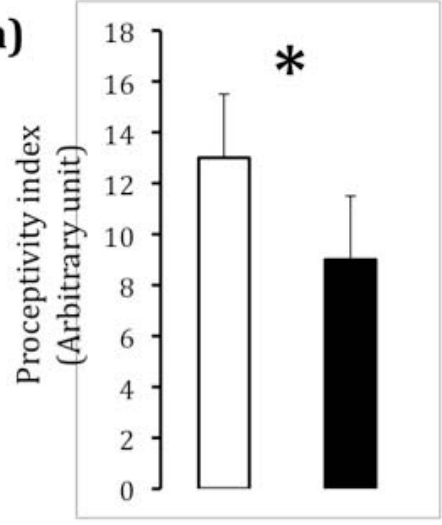

d)

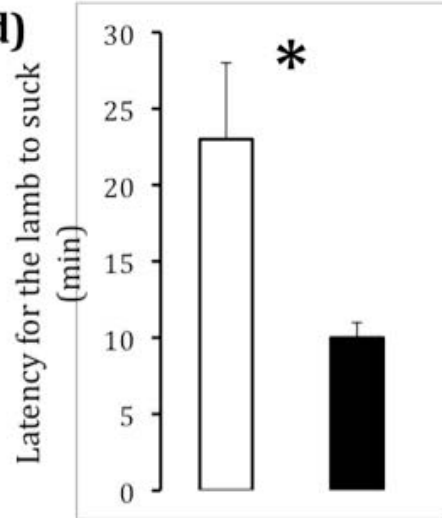

b)

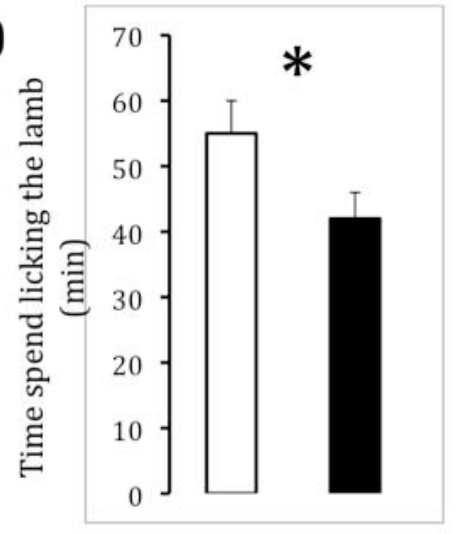

e)

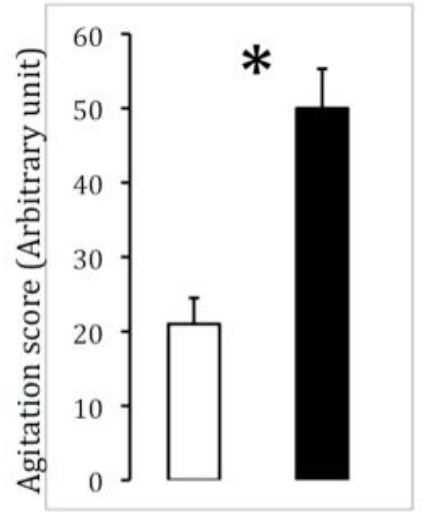

c)

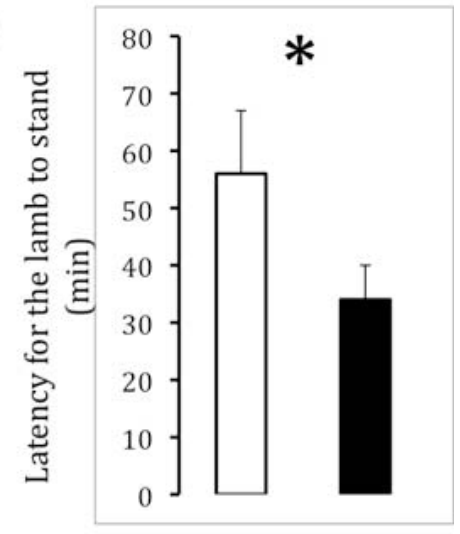

f)

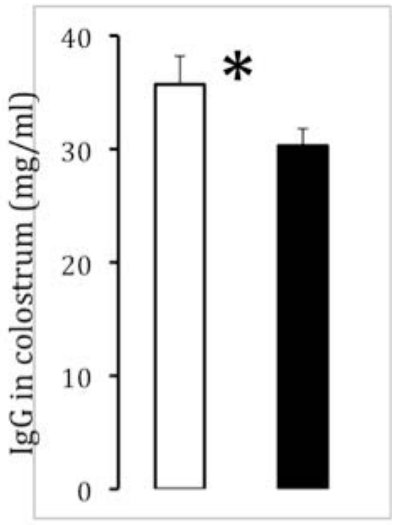

Figure 1 - Effect of selection for calm temperament (open bar) nervous temperament (close bar) on a) the expression of proceptivity in experienced ewes at $32 \mathrm{H}$ after removal of intravaginal progesterone device, b) time spend licking the newborn lamb, c) latency of the lamb to stand after birth d) latency of the lamb to suck after birth e) concentration of IgG in the colostrum of in single bearing ewes and f) agitation of 1 week old lambs. Data adapted from (Gelez et al., 2003; Hart et al., 2006; Bickell et al., 2009b; Bickell et al., 2010b).

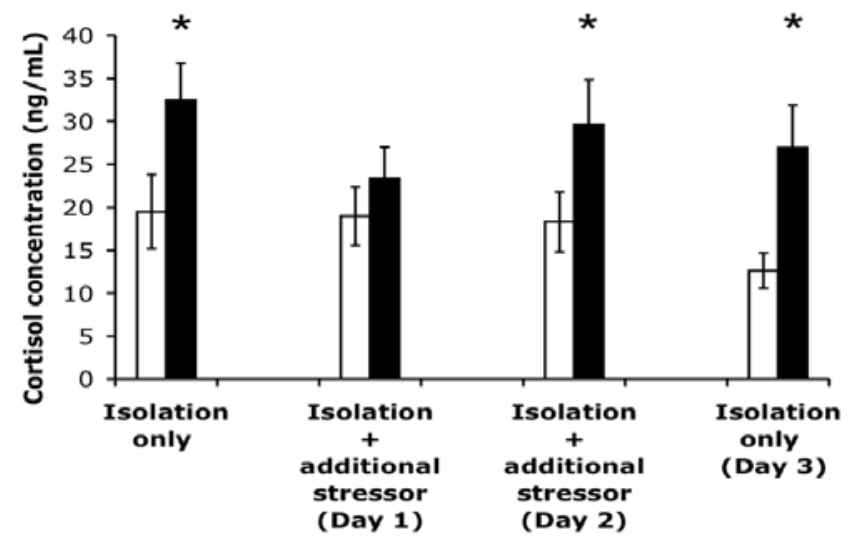

Figure 2 - Mean \pm SEM concentrations of cortisol in nervous (black bars; $\mathrm{n}=8$ ) and calm (white bars; $\mathrm{n}=8$ ) sheep during social isolation with or without an additional stressor. Ewes were either repeatedly exposed to 10 minutes of social isolation or social isolation with an additional stressor on Days 1 and 2 that was removed on Day 3. $* \mathrm{P}<0.05$ (Bickell \& Blache unpublished data).

\section{Early gestation}

In sheep, the number of ovulations can be affected by the level of nutrition (Scaramuzzi et al., 2006) and the genotype of the sheep such as sheep that carry the FecB (Booorola) gene (Bindon et al., 1986). Recently, we have shown that temperament can affect ovulation where ewes of a calm temperament have a greater ovulation rate than nervous ewes (Hart et al., 2008). At the beginning of the breeding season, the same proportion of calm and nervous ewes were spontaneously cyclic (about $30 \%$ ), a proportion consistent for the Merino genotype in this environment (Pearce \& Oldham, 1998). However, calm ewes had a higher sponataneous ovulation rate compared to nervous ewes (1.63 v 1.26, $\mathrm{P}=0.003$ ) and a higher ovulation rate than nervous ewes (1.83 $\mathrm{v} 1.57, \mathrm{P}=0.03)$ in response to synchronization using intravaginal progestagen and an injection of eCG. More multiple gestations were observed in calm ewes than nervous ewes on Day 74 (Calm $1.60 \mathrm{v}$ Nervous $1.35, \mathrm{P}=0.03$ ) but the pregnancy rate was similar in 
both lines (Hart et al., 2008). Ewes of calm temperament also carried more twin embryos than nervous ewes (1.39 embryos, $\mathrm{n}=472: 1.29$ embryos, $\mathrm{n}=302 ; \mathrm{p}<0.001$ ) and this has been observed over multiple years while the two lines were managed as one flock except at mating and lambing (Table 1). The biological mechanisms behind the differences in ovulation rate and twin bearing percentage have not been truly investigated, but we propose that differences in energy partitioning could account for these differences in ovary function (Blache et al., 2008).

\section{Survival of the young}

Early studies conducted at The University of Western Australia between 1990 and 1995 found that lambs born from calm mothers have a higher chance of survival between birth and weaning (Murphy et al., 1994; Murphy, 1999). It was proposed that lamb mortality was reduced in the calm ewes because they were better mothers than nervous ewes as they spent more time with their lamb(s) and, when disturbed, had a shorter flight distance and returned to their lamb(s) sooner (Murphy et al., 1994; Murphy, 1999). The incidence of lamb mortality, birth to weaning, was about half for calm ewes compared to nervous ewes, independent of the physical status of the lambs (Murphy et al., 1994; Murphy, 1999). More recently, we have conducted a number of trials to closely examine the behavioural and physiological basis of the differences between the 2 selected lines. Under indoor conditions and using a smaller number of animals than used by Murphy (1999), we did not record a difference in the maternal behaviour of the calm and nervous ewes (Bickell et al., 2010a). These results were supported by the fact that hormonal profiles of steroids known to influence maternal behaviour (Dwyer et al., 2004) were only slightly different between the two genotypes (Bickell et al., 2010a). It is possible that the indoor conditions were not challenging enough for the differences in maternal behaviour to be seen (for details see (Bickell et al., 2010a)). In outdoors conditions and with minimal human disturbance, temperament does influence the early post partum behaviour of ewes and

Table 1 - Percentage of lambs weaned to ewes joined over four year. The ewes were kept at one flock except during mating, they had very limited contact with human during the first 4 weeks after birth

\begin{tabular}{cccc}
\hline Year & Calm & Nervous & Difference \\
\hline 2001 & 64 & 45 & 19 \\
2002 & 74 & 64 & 10 \\
2003 & 83 & 67 & 16 \\
2004 & 92 & 80 & 12 \\
\hline
\end{tabular}

lambs (Bickell et al., 2010b). Calm ewes licked their lambs more and tended to stay longer on the birth site than the nervous ewes (Figure 1b), as previously reported by (Murphy, 1999). In line with the high level of activity of the nervous lambs during behavioural tests at one week (see above (Bickell et al., 2009a)), nervous lambs stood up earlier and were quicker to start performing exploratory behaviour than calm lambs (Figure 1c). As a result, nervous lambs start suckling earlier than calm lambs (Figure 1d).

The survival of the lamb is strongly influence by the rapid establishment of a strong mother-lamb bond soon after birth (Nowak, 2006). We investigated the impact of the selection for temperament on mother-young recognition using a standardized two-choice test (Bickell et al., 2009a). Calm and nervous multiparous ewes and their lambs showed a similar preference for their familiar kin at 6 and18 h after birth. Our results suggest that temperament does not affect the early process of ewe-lamb bonding. However, during the same experiment, we found that nervous lambs showed higher vocal and locomotor activity than calm lambs and that differences in temperament, measured as their agitation during behavioural tests were already detectable at 1 weeks of age (Figure 1e; Bickell et al., 2009a). This high level of motor activity could explain in part the high incidence of mortality in nervous lamb because it might increase the chance of separation from their mother in a field situation.

Lamb mortality during the first 3 days after birth, which represent $80 \%$ of lamb deaths before weaning is also caused by starvation due to inadequate energy intake (Watson, 1972; Alexander, 1984). A lamb’s first meal after birth is of great importance for the lamb's survival because it facilitates the establishment of the ewe-lamb bond and provides energy and immune protection to the lamb (Nowak et al., 2008). The duration that ewes suckled their lambs in outdoor conditions did not differ between temperament lines (Bickell et al., 2010b) and the quantity of colostrum produced over the first 12 hours after parturition was similar between the two lines (Hart et al., 2006). However, while the time that lambs spent sucking might have been similar, the quantity of nutrients ingested may have been different because the colostrum of calm ewes may have be easier to suck as it is less viscous than that produced by the nervous ewes (Hart et al., 2006). Over the first 10 hours after parturition, the colostrum produced by calm ewes contains slightly more lactose and fat than that produced by nervous ewes (Figure 1; Hart et al., 2006). More importantly, the concentration of Immunoglobulin-G (IgG), the most abundant Ig in ewe colostrum, was greater in the 
colostrum of calm ewes than in the colostrum of nervous ewes (Figure 1f; Hart et al., 2009). At birth, the concentration of serum immunoglobulins (Ig) in the plasma of lambs is close to nil (Parker \& Nicol, 1990), lambs must absorb Ig from their mother's colostrum to acquire immunity and increase their chance of survival. Therefore lambs born from calm ewes have access to a larger quantity of Ig and passively acquire immune competency better than lambs born from nervous ewes.

\section{Final Considerations}

We have demonstrated some effects of selection for temperament on the reproductive biology of Merino sheep (Figure 3). The mechanisms by which the genetic selection for temperament has such effects are largely unknown. It is possible that the selection for temperament has resulted in a co-selection for high ovulation rate. Alternatively, differences in energy requirement, nervous animals spending more energy to express their behaviours and therefore energy partitioning could be responsible for specific effects such as the increase in ovulation rate. The effect of temperament on the care and survival of the young is a complex phenomenon with no obvious clearcut answer and requires further investigation especially regarding the importance of the presence of stressors (fearful events or nutritional stress) during early stages after parturition. The results presented here only highlight the complexity of the factors affecting lamb survival and showed that, should temperament affect lamb survival, it is not by acting only on the establishment of the ewelamb bond. Other possible effects of selection for temperament have not received attention so far. Selection of temperament, which changes the response to stress, could affect embryo survival and organ development because of the importance of stress on those intrauterine events. Overall, this type of selection has a great potential to improve reproduction and therefore productivity in sheep but also, if the method selection are/were available, other domestic ruminants.

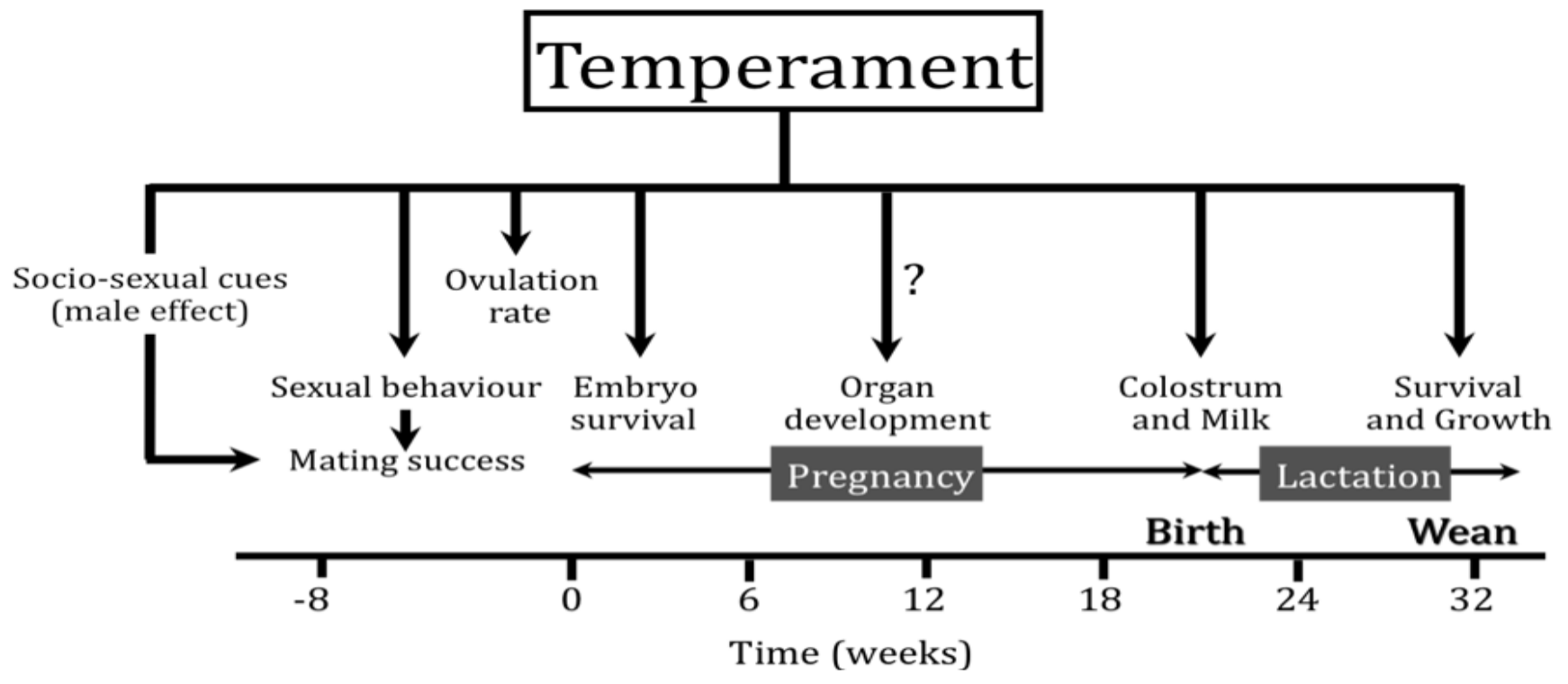

Figure 3 - Diagram summarising the effects of selection for calm or nervous temperament on the reproductive biology of Merino sheep. Question mark indicate event of the reproductive cycle that are potential target for temperament but haven't been investigated yet. 


\section{Acknowledgements}

The studies from our group at UWA reviewed here could not have been contemplated without the generous assistance of the students and staff of Animal Science (University of WA), the collaboration with scientists from CSIRO Armidale, Australia and INRA Nouzilly and ClermontFerrand, France, and a long list of visiting students from all over the world. Thanks to all.

\section{References}

ALEXANDER, G. Constraints to lamb survival. In: LINDSAY, D.R.; PEARCE, D.T. (Eds.) Reproduction in sheep. Canberra: Australian Academy of Science, Australian Wool Corporation, 1984. p.199-209.

BICKELL, S.L.; NOWAK, R.; POINDRON, P. et al. Temperament does not affect the overall establishment of mutual preference between the mother and her young in sheep measured in a choice test. Developmental Psychobiology, v.51, p.429438, 2009a.

BICKELL, S.L.; POINDRON, P.; NOWAK, R. et al. Genotype rather than non-genetic behavioural transmission determines the temperament of Merino lambs. Animal Welfare, v.18, p.459-466, 2009b.

BICKELL, S.L.; POINDRON, P.; NOWAK, R. et al. Maternal behaviour and peripartum levels of oestradiol and progesterone show little differences in Merino ewes selected for calm or nervous temperament under indoor housing conditions. Animal, 2010a (in press).

BICKELL, S.L.; POINDRON, P.; NOWAK, R. et al. Maternal behaviour at parturition in outdoor conditions differs only moderately between single bearing ewes selected for their calm or nervous temperament. Animal Production Science, v.50, 2010b (accepted).

BINDON, B.M.; PIPER, L.R.; CAHILL, L.P. et al. Genetic and hormonal factors affecting superovulation. Theriogenology, v.25, p.53-70, 1986.

BLACHE, D.; FERGUSON, D. Increasing sheep meat production efficiency and animal welfare by selection for temperament. Sydney: Meat and Livestock Australia, 2005. (Final report SHGEN, 025).

BLACHE, D.; MARTIN, G.B.; MALONEY, S.K. Towards ethically improved animal experimentation in the study of animal reproduction. Reproduction in Domestic Animals, v.43, p.814, 2008 (suppl. 2).

BLACHE, D.; ZHANG, S.; MARTIN, G.B. Fertility in males: modulators of the acute effects of nutrition on the reproductive axis of male sheep. In: CAMPBELL, B.K.; WEBB, R.; DOBSON, H. et al. (Eds.) Reproduction in domestic ruminants V. Cambridge: Society for Reproduction and Fertility, 2003. p.387-402.

BLACHE, D.; ZHANG, S.; MARTIN, G.B. Dynamic and integrative aspects of the regulation of reproduction by metabolic status in male sheep. Reproduction Nutrition Development, v.46, p.379-390, 2006.

BOISSY, A. Fear and fearfulness in animals. The Quarterly Review of Biology, v.70, 165-191, 1995.

BOISSY, A.; MANTEUFFEL, G.; JENSEN, M.B. et al. Assessment of positive emotions in animals to improve their welfare. Physiology \& Behavior, v.92, p.375-397, 2007.

CANNON, W.B. The James-Lange theory of emotions: a critical examination and an alteration. American Journal Psychology, v.39, p.106-124, 1927.
CHANVALlON, A.; BLACHE, D.; CHADWICK, A. et al. Sexual experience and temperament affect the response of Merino ewes to the ram effect during the anoestrous season. Animal Reproduction Science, v.119, p.205-211, 2010.

DARWIN, C. The expression of the emotions in man and animals. London: John Murray, 1872. 277p.

DELGADILLO, J.A.; GELEZ, H.; UNGERFELD, R. et al. The 'male effect' in sheep and goats - Revisiting the dogmas. Behavioural Brain Research, v.200, 304-314, 2009.

DWYER, C.M.; GILBERT, C.L.; LAWRENCE, A.B. Prepartum plasma estradiol and postpartum cortisol, but not oxytocin, are associated with interindividual and breed differences in the expression of maternal behaviour in sheep. Hormonal Behavior, v.46, p.529-543, 2004.

FELL, L.R.; COLDITZ, I.G.; WALKER, K.H. et al. Associations between temperament, performance and immune function in cattle entering a commercial feedlot. Australian Journal of Experimental Agriculture, v.39, p.795-802, 1999.

FORKMAN, B.; BOISSY, A.; MEUNIER-SALAUN, M.C. et al. A critical review of fear tests used on cattle, pigs, sheep, poultry and horses. Physiology \& Behavior, v.91, p.531-565, 2007.

GELEZ, H.; LINDSAY, D.R.; BLACHE, D. et al. Temperament and sexual experience affect female sexual behaviour in sheep. Applied Animal Behaviour Science, v.84, p.81-87, 2003.

GREIVELDINGER, L.; VEISSIER, I.; BOISSY, A. Emotional experience in sheep: predictability of a sudden event lowers subsequent emotional responses. Physiology \& Behavior, v.92, p.675-683, 2007.

HAFEZ, E.S.E.; LINDSAY, D.R. Behavioral responses in farm animals and their relevance to research technique. Animal Breeding Abstract, v.33, p.1-16, 1965.

HART, K.; VAN LIER, E.; VIÑOLES, C. et al. Calm Merino ewes have more multiple pregnancies than nervous Merino ewes due to higher ovulation rate. Reproduction in Domestic Animals, v.43, p.88, 2008 (suppl 3).

HART, K.W.; CHADWICK, A .; SÉBÉ, F. et al. Colostrum quality of ewes of calm temperament is not responsible for low lamb mortality. Australian Journal of Agricultural Research, v.46, p.827-829, 2006.

HART, K.W.; CONTOU, C.; BLACKBERRY, M. et al. Merino ewes divergently selected for calm temperament have a greater concentration of immunoglobulin $\mathrm{g}$ in their colostrum than nervous ewes. Proceedings of the Association for the Advancement of Animal Breeding and Genetics, v.18, p.576-579, 2009.

KING, D.A.; SCHUEHLE PFEIFFER, C.E.; RANDEL, R.D. et al. Influence of animal temperament and stress responsiveness on the carcass quality and beef tenderness of feedlot cattle. Meat Science, v.74, p.546-556, 2006.

LE NEINDRE, P.; MURPHY, P.M.; BOISSY, A. et al. Genetics of maternal ability in cattle and sheep. In: WORLD CONGRESS ON GENETICS APPLIED TO LIVESTOCK PRODUCTION, 6., 1998, Armidale. P roceedings... Armidale: 1998. p.23-30.

MANTECA, X.; DEAG, J.M. Individual differences in temperament of domestic animals: a review of methodology. Animal Welfare, v.2, p.247-268, 1993.

MURPHY, P.M. Maternal behaviour and rearing ability of Merino ewes can be improved by strategic feed supplementation during late pregnancy and selection for calm temperament. 1999. PhD Thesis - The University of Western Australia, Perth.

MURPHY, P.M.; PURVIS, I.W.; LINDSAY, D.R. et al. Measures of temperament are highly repeatable in Merino sheep and some are related to maternal behaviour. Australian Society of Animal Production Proceedings, v.20, p.247-250, 1994.

NOWAK, R.; POINDRON, P. From birth to colostrum: early steps leading to lamb survival. Reproduction Nutrition Development, v.46, p.431-446, 2006. 
NOWAK, R.; PORTER, R.H.; BLACHE, D. et al. Behaviour and welfare of sheep. In: DWYER, C.M. (Ed.) The welfare of sheep. Berlin: Springer, 2008. p.81-134.

PARKER, R.J.; ICOL, A.M. A measure of serum immunoglobulin concentration to estimate lamb colostrum intake. Proceedings of the New Zeland Society of Animal Production, v.50, p.275-278, 1990.

PEARCE, D.T.; OLDHAM, C.M. Ovulation in the Merino ewe in the breeding and anoestrous seasons. Australian Journal of Biological Sciences, v.41, p.23-26, 1998.

PHOCAS, F.; BOIVIN, X.; SAPA, J. et al. Genetic correlations between temperament and breeding traits in Limousin heifers. Animal Science, v.82, p.805-811, 2006.

PRICE, E.O. Animal domestication and behavior. Wallingford: CAB International, 2002. 320p.

PUTU, G. Maternal behaviour in merino ewes duringthe first two days after parturition and survival of the lamb. 1988. PhD Thesis - The University of Western Australia, Perth, $164 p$.

RAUW, W.M.; KANIS, E.; NOORDHUIZEN-STASSEN, E.N. et al. Undesirable side effects of selection for high production efficiency in farm animals: a review. Livestock Production Science, v.56, p.15-33, 1998.
ROSA, H.J.D.; BRYANT, M.J. Seasonality of reproduction in sheep. Small Ruminant Research, v.48, p.155-171, 2003.

SCARAMUZZI, R.J.; CAMPBELL, B.K.; DOWNING, J.A. et al. A review of the effects of supplementary nutrition in the ewe on the concentrations of reproductive and metabolichormones and the mechanisms that regulate folliculogenesis and ovulation rate. Reproduction Nutrition Development, v.46, p.339354, 2006.

SCHMUTZ, S.M.; STOOKEY, J.M.; WINKELMAN-SIM, D.C. et al. A QTL study of cattle behavioral traits in embryo transfer families. Journal of Heredity, v.92, p.290-292, 2001.

VOISINET, B.D.; GRANDIN, T.; TATUM, J.D. et al. Feedlot cattle with calm temperaments have a higher average daily weight gains the cattle with excitable temperaments. Journal of Animal Science, v.75, p.892-896, 1997.

VON BORELL, E.; DOBSON, H.; PRUNIER, A. Stress, behaviour and reproductive performance in female cattle and pigs. Hormones and Behavior, v.52, p.130-138, 2007.

WATSON, R.H. Observed levels of mortality in relation to lambing and early stages of growth of sheep in Australia. World Review of Animal Production, v.8, p.104-113, 1972.

WILLIS, M.B. Dalton's introduction to practical animal breeding. Oxford: Blackwell Scientific Publications, 1991. 166p. 